\title{
DEVELOPMENT OF RICE SEEDLINGS GROWN FROM PRE-HYDRATED SEEDS AND IRRADIATED WITH GAMMA RAYS
}

\author{
Desenvolvimento de plântulas de arroz oriundas \\ de sementes pré-hidratadas e irradiadas com raios gama
}

\author{
Aline Scheer da Silva ${ }^{1}$, Rodrigo Danielowski², Eugenia Jacira Bolacel Braga ${ }^{1}$, \\ Sidnei Deuner ${ }^{3}$, Ariano Martins de Magalhães Junior ${ }^{4}$, Jose Antonio Peters ${ }^{1}$
}

\begin{abstract}
Techniques used to induce mutations, such as ionizing radiation, are an effective tool in increasing genetic variability in breeding programs of species of economic interest. This study aimed to evaluate the effect of different doses of $\mathrm{Co}^{60}$ gamma radiation on previously soaked seeds on the emergence and early growth of seedlings of two rice cultivars. To do this, seeds (25\% moisture) of BRS Querência and BRS Fronteira were irradiated with zero (control), 50, 100, 150 and $200 \mathrm{~Gy}$, and then sown in trays containing soil and kept in a greenhouse. The results showed that gamma radiation affected seedling development, where the highest dose tested (200 Gy) significantly reduced the emergence and the index of emergence speed. Growth parameters were reduced greater reduction in cv. BRS Querência. For antioxidant enzymes, superoxide dismutase expressed little variation for the periods evaluated. Already ascorbate peroxidase and catalase showed a significant increase in horsepower cv. BRS Fronteira at 14 DAS, followed by an increase in both cultivars ascorbate peroxidase activity at 28 DAS. The highest antioxidant capacity observed in cv. BRS Fronteira conferred greater tolerance to stress caused by gamma radiation.
\end{abstract}

Index terms: Oryza sativa L., humidity, genetic variability.

\section{RESUMO}

Técnicas como radiações ionizantes, utilizadas para induzir mutações constituem ferramenta eficaz no aumento de variabilidade genética em programas de melhoramento de espécies de interesse econômico. Neste trabalho, objetivou-se verificar o efeito de diferentes doses de radiação gama $\mathrm{Co}^{60} \mathrm{em}$ sementes previamente embebidas sobre a emergência e o crescimento inicial de plântulas de duas cultivares de arroz. Lotes de sementes com $25 \%$ de umidade das cultivares BRS Querência e BRS Fronteira foram irradiados com doses de zero (controle), 50, 100, 150 e 200 Gy, sendo, em seguida, semeadas em bandejas contendo solo e mantidas em casa de vegetação. Os resultados mostraram que a radiação gama afetou o desenvolvimento das plântulas, sendo que a maior dose testada (200 Gy) reduziu, significativamente, a emergência e o índice de velocidade de emergência. Os parâmetros de crescimento apresentaram maior redução na cv. BRS Querência. Na atividade das enzimas antioxidantes, a superóxido dismutase expressou pouca variação para os períodos avaliados. Já, a ascorbato peroxidase e catalase mostraram expressivo aumento na cv. BRS Fronteira aos 14 DAS, seguidas de incremento para as duas cultivares na atividade da ascorbato peroxidase aos 28 DAS. A maior capacidade antioxidante observada na cv. BRS Fronteira conferiu uma maior tolerância ao estresse causado pela radiação gama.

Termos para indexação: Oryza sativa L., umidade, variabilidade genética.

(Received in may 16, 2011 and approved in august 22, 2011)

\section{INTRODUCTION}

Irrigated rice has great economic and social importance, especially in southern Brazil, which encourages the pursuit of more productive varieties with agronomic characteristics that meet market requirements. Among the newly released cultivars in the south region of the country, are BRS Querência and BRS Fronteira, which although productive, have some issues that need to be improved, such as cycle reduction and increased tolerance to blast and cold.
Techniques to support conventional breeding programs, such as tissue culture, genetic transformation, molecular markers or induced mutations, are being used in various research institutions (FU et al., 2008) in order to increase competitiveness and product quality on the world market. In that context, induced mutations are a widely used tool for increasing genetic variability (GAUL, 1970; FU et al., 2008), especially if the genetic base is relatively narrow within the species (KUMAR, 1991). Through the use of gamma radiation, a number of mutants were obtained

\footnotetext{
'Universidade Federal de Pelotas/UFPel - Instituto de Biologia - Departamento de Botânica - Capão do Leão - RS - Brasil

2Universidade Federal de Pelotas/UFPel - Capão do Leão - RS - Brasil

${ }^{3}$ Embrapa Cerrados - BR 020, km 18 - Planaltina - DF - Brasil - sidnei.deuner @cpac.embrapa.br

${ }^{4}$ Emprapa Clima Temperado - Estação Experimental Terras Baixas - Pelotas - RS - Brasil
} 
with characteristics of higher productivity, precocity, smaller size, and enhanced resistance to pests and diseases in different species, which were used in breeding programs to obtain new cultivars (HAQ, 1971). In that respect, using irradiation, current estimates indicate that more than 2,200 varieties of plants were already obtained. It is noteworthy that $64 \%$ of these were obtained by gamma radiation (AHLOOWALIA et al., 2004; WU et al., 2005). With regards to irrigated rice, the introduction of cultivars ClearField (CL) obtained by induced mutation, has led to higher yields coupled with the better control of red rice (FAGUNDES; ANDRES, 2008).

There is evidence that the water content of the seeds makes them more sensitive to the action of mutagens, and seeds imbibed before irradiation are much more radiosensitive than dry seeds (MIRANDA, 2009). Literature data shows that hydroxyl radicals $\left(\mathrm{OH}^{-}\right)$can be separated from water molecules by ionizing radiation and react with atoms of $\mathrm{H}^{+}$derived from the DNA structures, inducing changes in these molecules, thereby stimulating increased mutation rate (HUNG; JOHNSON, 2008).

In plants, the oxidative response may be intensified under stressful conditions (GRATÃO, 2005) and in this way, antioxidant enzymes are being studied in response to abiotic stresses (DEUNER et al., 2011). At the cellular level, proteins and membranes can be damaged by increases in reactive oxygen species (ROS) (ARTLIP; WISNIEWSKI, 2002). However, to avoid the accumulation of ROS and protect cells from oxidative damage, plants possess an enzymatic and a non-enzymatic antioxidant defense system and allowing detoxification of these substances. This defense mechanism requires the action of several enzymes acting in concert, such as superoxide dismutase (SOD), catalase (CAT) and ascorbate peroxidase (APX) (GRATÃO et al., 2005).

Although research with radiation aims mainly at obtaining mutants, which can become new cultivars or serve in backcross breeding programs, it is important to determine the effect of the radiation in the early stages of plant development. Thus, the objective of the present study was to evaluate the effect of different levels of $\mathrm{Co}^{60}$ gamma radiation in seeds previously water-imbibed, on emergence, early growth and antioxidant enzymes response in seedlings of two rice cultivars.

\section{MATERIAL AND METHODS}

The experiments were conducted in a greenhouse at Embrapa Temperate Climate, located in Pelotas, RS Brazil. Dry rice seeds (13\% moisture) of BRS Querência and BRS Fronteira were hydrated with distilled water to
$25 \%$ humidity. To determine the desired moisture, the formula described by Cromarty et al. (1982), based on variation in seed mass [initial mass $=$ final mass $\mathrm{x}(100$ initial moisture content $) /(100$ - final moisture content $)]$ was used.

After the hydration process, the seeds were stored in Petri dishes and transferred for cooling to $10^{\circ} \mathrm{C}$ for 48 hours until they reached a constant mass. After the confirmation of $25 \%$ humidity, they were immediately irradiated at the following doses: 0, 50, 100, 150 and 200 Gy, with a source of $\mathrm{Co}^{60}$ "Eldorado 78" (Atomic Energy of Canada Ltd.) of the Oncology Center, Department of Radiology, Medicine Faculty, UFPel. The different radiation dosages were obtained by varying the exposure time of seeds, with a rate of 17.35 Gy per minute. For each cultivar and dose, lots of 500 seeds were irradiated. Subsequently, they were immediately sown in plastic trays containing soil type "Planossolo Háplico", which is typical torice growing areas, retaining moisture through manual irrigation.

Initially, the percentage of emergency was analyzed 14 days after sowing (DAS) and the index of emergence speed (IES), as determined by the formula described by Popinigis (1977), with daily counts of the number of emerged seedlings until the stabilization of the stand. Also at 14 and at 28 DAS, 60 seedlings of each treatment were randomly harvested and evaluated height $(\mathrm{cm})$, number of leaves (n), main root length $(\mathrm{cm})$ and shoots and roots dry biomass (g), per seedling, after drying in an oven at $70^{\circ} \mathrm{C}$ for 72 hours.

To evaluate the effect of radiation on antioxidant metabolism, the activity of superoxide dismutase (SOD), catalase (CAT) and ascorbate peroxidase (APX) were quantified in plant extracts obtained from recently-imbibed seeds and in seedlings irradiated at 10 DAS. Two hundreds micrograms of plant material were macerated and homogenized in $20 \%$ polyvinylpyrrolidone (PVPP), added of the following extraction buffer: $100 \mathrm{mM}$ potassium phosphate (pH 7.8), $0.1 \mathrm{mMEDTA}$ and ascorbic acid (ASA) $1 \mathrm{mM}$. The homogenates were centrifuged at 13,000 rpm for 20 minutes at $4^{\circ} \mathrm{C}$ and the supernatant collected for subsequent enzymatic analysis.

The SOD activity was assessed by the ability of the enzyme to inhibit the photoreduction of nitrotetrazolium blue (NTB) (GIANNOPOLITIS; RIES, 1977) in the reaction medium composed of $100 \mathrm{mM}$ potassium phosphate $(\mathrm{pH}$ 7.8), $14 \mathrm{mM}$ methionine , $0.1 \mu \mathrm{M}$ EDTA, $75 \mu \mathrm{M}$ NBT and riboflavin $2 \mu \mathrm{M}$. Readings were taken at $560 \mathrm{~nm}$, and a unit of SOD is the amount of enzyme capable of inhibiting by $50 \%$ in the photoreduction of NTB in the test conditions. CAT activity was determined as described by Azevedo et 
al. (1998) with some modifications. The activity was monitored by the decrease in absorbance at $240 \mathrm{~nm}$ during 2 minutes in reaction medium incubated at $28^{\circ} \mathrm{C}$. This medium contained $100 \mathrm{mM}$ potassium phosphate buffer ( $\mathrm{pH} 7.0$ ) and $12.5 \mathrm{mM} \mathrm{H}_{2} \mathrm{O}_{2}$. The activity of APX was performed, by monitoring the rate of oxidation of ascorbate at $290 \mathrm{~nm}$. The incubation buffer was composed of 100 $\mathrm{mM}$ potassium phosphate, $\mathrm{pH} 7.0$, ascorbic acid $0.5 \mathrm{mM}$ and $0.1 \mathrm{mM} \mathrm{H}_{2} \mathrm{O}_{2}$.

The experiment was established according to a completely randomized factorial $2 \times 5$ design (two cultivars and five doses of radiation) with six replicates. Each experimental unit consisted of 80 seeds for the variables, percentage of emergency and IES. Other evaluations were conducted with six replicates, being the experimental unit consisted of 10 seedlings. Statistical analysis was performed separately according to the sampling dates (14 and 28 DAS). The experimental data were subjected to an analysis of variance and means were compared by a Tukey test $(1 \%$ probability) and polynomial regression using the Statistical Analysis System - SANEST (ZONTA; MACHADO, 1984).

\section{RESULTS AND DISCUSSION}

The cultivar BRS Querência showed a higher emergence percentage and also a higher index of emergence speed (IES) in comparison to cv. BRS Fronteira in the control treatment $(0 \mathrm{~Gy})$ and in the lower radiation doses tested. However, doses higher than 100 Gy significantly affect seedling emergence in both cultivars and also the IES for cultivar BRS Querência. The cultivar BRS Fronteira, however, showed decreases in seeds IES in all radiation treatments compared to the control, the most drastic reduction being observed at a dose $200 \mathrm{~Gy}$, highly significant for all variables (Table 1). The response at a dose 200 Gy confirms the greater effect of the mutagen when the seeds have a high percentage of hydration, because previous studies with the same dose in seeds with $13 \%$ humidity, of the same cultivar, did not differ from control treatment, presenting with dose $200 \mathrm{~Gy}$ an average emergency of $85 \%$ of and an IES of 13.2 (data not shown). Similar results were found by Miranda et al. (2009) that verified differences with the same doses in wet (artificially aged) and dried rice seeds, even using low doses of radiation (1 and 5 Gy).

Seedling height is widely used as an index in determining the biological effects of various physical and chemical mutagens. The height of the seedlings was negatively affected by the use of radiation for cultivar BRS Querência in the two analyzed periods, and the response was linear and decreasing, with reductions of $31.4 \%$ (dose 150 Gy at 14 DAS) and $27.5 \%$ when using 200 Gy at 28 DAS (Figures 1A and 1B). For cultivar BRS Fronteira, in both evaluation dates, there was an increase in this trait at doses of 50, 100 and $150 \mathrm{~Gy}$. The better response was obtained with $50 \mathrm{~Gy}$ (25.6\% compared to control). Similar results for cultivar BRS Querência were obtained by Rodrigues eAndo (2002) while evaluating the height of upland rice seedlings subjected to 120 and $360 \mathrm{~Gy}$. However, stimulating effects of low doses of ionizing radiation, as observed in cv. BRS Fronteira, has been reported in rice (CHEEMA; ATTA, 2003; MAITY et al., 2005) and soybean (DELA et al., 2000). Cepero et al., (2001) observed maximum stimulating effect of low doses (150 and $180 \mathrm{~Gy}$ ) on seedling height of Leucaena leucocephala $\mathrm{cv}$. Cunningham. The lower doses of gamma radiation are concluded to produce a stimulus on the growth of the aerial as well as the underground parts.

The number of leaves per seedling at 14 DAS was not significant between treatments in cultivar BRS Fronteira, while there was a slight decrease in this character considering the dose $50 \mathrm{~Gy}$ in cultivar BRS Querência, i.e. a reduction of $15.7 \%$ when compared to control (Figure 1C). With regards to the evaluation that took place $28 \mathrm{DAS}$, both cultivars showed the same trend, with a positive stimulus in this parameter in the treatments of 150 and 200 Gy (Figure 1D).

Table 1 - Emergence percentage at 14 days after sowing (DAS) and index of emergence speed (IES) of seedlings from two rice cultivars (BRS Querência and BRS Fronteira) subjected to different doses of $\mathrm{Co}^{60}$ gamma radiation.

\begin{tabular}{ccccc}
\hline & \multicolumn{2}{c}{$\%$ Emergence } & & IES \\
Dose (Gy) & BRS Querência & BRS Fronteira & BRS Querência & BRS Fronteira \\
\hline Control & $91.0 \mathrm{a}$ & $80.7 \mathrm{a}$ & $24.7 \mathrm{a}$ & $23.6 \mathrm{a}$ \\
50 & $86.5 \mathrm{ab}$ & $74.2 \mathrm{ab}$ & $23.7 \mathrm{a}$ & $20.2 \mathrm{~b}$ \\
100 & $83.5 \mathrm{~b}$ & $77.0 \mathrm{~b}$ & $22.7 \mathrm{a}$ & $20.1 \mathrm{~b}$ \\
150 & $70.2 \mathrm{c}$ & $72.7 \mathrm{~b}$ & $18.4 \mathrm{~b}$ & $19.8 \mathrm{~b}$ \\
200 & $33.2 \mathrm{~d}$ & $34.7 \mathrm{c}$ & $6.3 \mathrm{c}$ & $5.3 \mathrm{c}$ \\
\hline
\end{tabular}

*Means followed by the same letter on the columns, do not differ statistically by the Tukey test at $1 \%$ of error probability. 

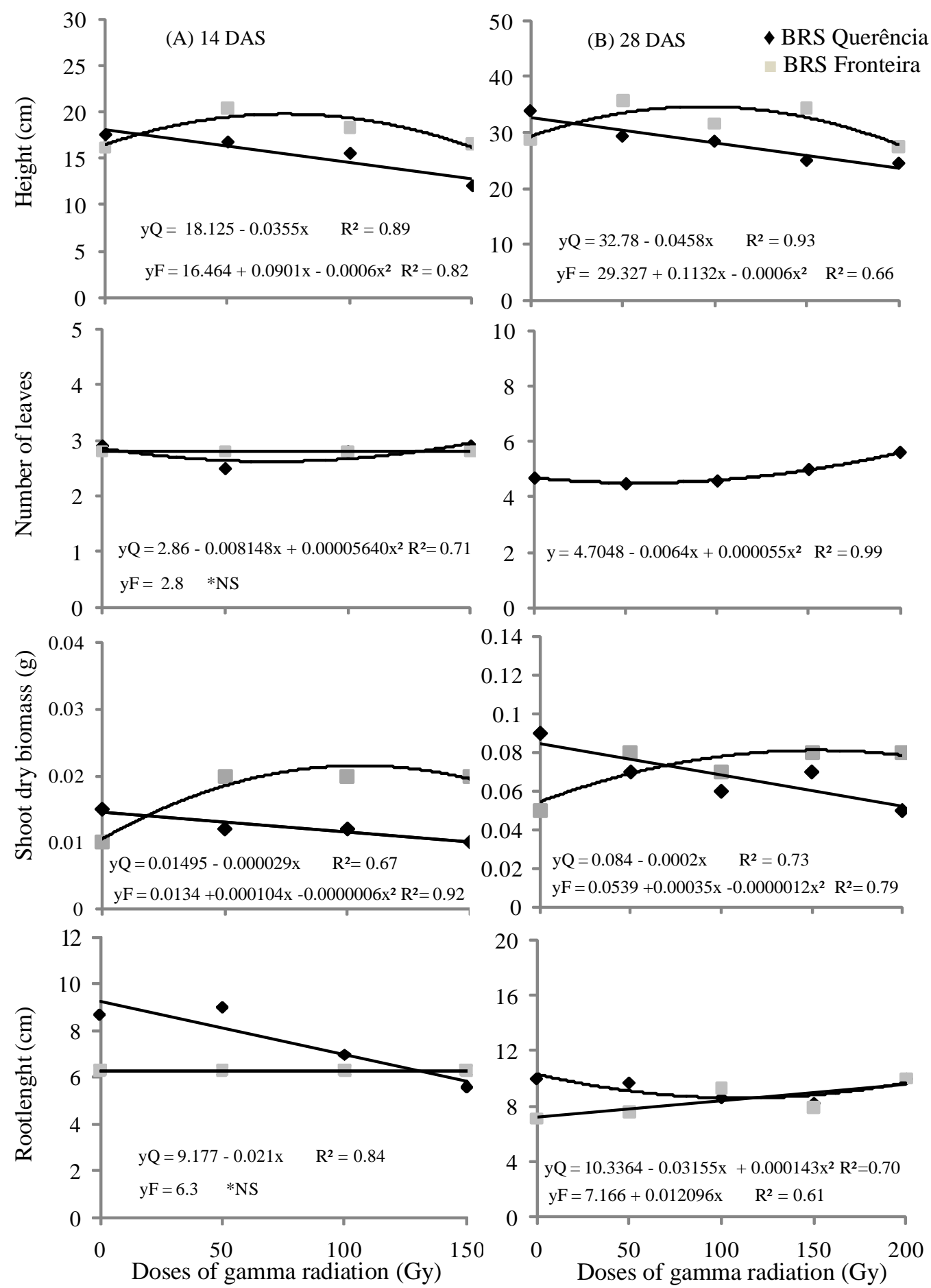

Figure 1 - Biometric parameters in two irrigated rice cultivars, BRS Querência ( ) and BRS Fronteira ( $($ ) subjected to different doses of gamma radiation $\left(\mathrm{Co}^{60}\right)$ evaluated at 14 (first column) and at 28 (second column) days after sowing (DAS).

Ciênc. agrotec., Lavras, v. 35, n. 6, p. 1093-1100, nov./dez., 2011 
With regards to the dry biomass of cultivar BRS Querência a linear decrease was observed according to the dose of radiation applied, regardless of the evaluation data, with a decrease of $33.3 \%$ at the 150 Gy dose at 14 DAS and $44.9 \%$ when using $200 \mathrm{~Gy}$ at 28 DAS (Figures 1E and $1 F)$. In contrast, the cultivar BRS Fronteira showed an increment in that trait with the use of gamma radiation on both evaluation dates, with an increase of $93.7 \%$ at 28 DAS *(using the highest tested dose). This difference in radio sensitivity between cultivars can be justified by the absence or low concentration of protective substances in the seeds of cv. BRS Querência (RODRIGUES; ANDO, 2002) or because that cv. BRS Fronteira has a slower metabolism.

As to the length of the roots, there was no difference between treatments for cultivar BRS Fronteira at 14 DAS, however, there was an increment in this parameter in the second evaluation, for the 200 Gy dose, with an increase of $41 \%$ compared to control (Figure $1 \mathrm{G}$ and $1 \mathrm{H}$ ). In previous studies with this cultivar, no significant differences between the 200 Gy dose and the control treatment were found (data not shown) when using seeds with $13 \%$ of humidity, confirming the observations of Viccini et al. (1997), which report that the water acts as a diffusion medium of physical and chemical mutagens, as well as of free radicals from the radiation process, since large amounts of water increases metabolic activity and thus enhance the seeds vulnerability to radiation.

For cultivar BRS Querência a significant decrease in root length was observed with increasing radiation doses of when measurements occurred at 14 DAS. This same trend, however, did not occur in the second assessment, reinforcing the results obtained in previous tests with seeds of this same cultivar with a moisture content of $13 \%$ (data not shown). It is noteworthy that at $14 \mathrm{DAS}$, no evaluations of the $200 \mathrm{~Gy}$ dose were performed due to the reduced number of emerging seedlings.

The different responses found among cultivars in relation to the parameters analyzed can be explained by the fact that the effects of gamma radiation are influenced by several factors including the gindividuals genotype (BAHL; GUPTA, 1982), the presence of some chemicals substances (KUMAR, 1991), the cell cycle phase (GUDKOV; GRODZINSKY, 1982), the degree of ploidy (BROCK, 1980), the DNA content per haploid genome (PLEWA et al., 1993) and oxygen level (BUMPet al., 1982). Thereby, reducing the biometric parameter settings may be partly due to the fact that the cells which have relatively more chromosomal damage at high irradiation exposures are at a disadvantage and cannot compete well with the normal cells and are thus prevented from making any further contribution (SHAH et al. 2008).

With regards to the dry biomass of roots at 14 DAS, no differences were observed between cultivars and treatments, averaging $0.009 \mathrm{~g}$ per plant. At 28 DAS there was no difference between cultivars, but with higher average values of dry matter and an average increase of $30 \%$ at the highest tested dose (data not shown). An increase in the dry biomass of seedlings was also observed by Miranda et al. (2009) in rice wet seeds irradiated with $5 \mathrm{~Gy}$.

As a consequence of the obtained results and making an analogy to the ratio between shoots and root system it can be verified that for the cultivar BRS Fronteira does of 50 and $100 \mathrm{~Gy}$ affected the development of the root more expressively, in both evaluations (Table 2). The same behavior was observed in cultivar BRS Querência with a dose of $100 \mathrm{~Gy}$ at 14 DAS and to $200 \mathrm{~Gy}$ at $28 \mathrm{DAS}$. These results demonstrated the existence of a distinct behavior between the two rice cultivars with regards to radiation doses, and that this variation also depends on the plant development stage.

In this study, SOD activity (Figures 2A and 2B), a key enzyme to the antioxidant defense mechanism, was not altered in the seeds of cultivar BRS Querência, but in the seedlings, there was an increase from the $100 \mathrm{~Gy}$ treatment onwards. In cultivar BRS Fronteira, the enzymatic behavior was different, as in seeds the enzyme activity increased at higher doses while in the seedlings activities increased at the doses of 50,100 and $150 \mathrm{~Gy}$. SOD is found in several cellular compartments and catalyzes the detoxification of $\mathrm{O}_{2}^{-}$to $\mathrm{H}_{2} \mathrm{O}_{2}$ and $\mathrm{O}_{2}$, thus preventing the formation of $\mathrm{OH}$ radical. However, the $\mathrm{H}_{2} \mathrm{O}_{2}$ is also toxic to the cell and must be detoxified by peroxidases or by CAT. The APX and CAT are enzymes that catalyze the conversion of $\mathrm{H}_{2} \mathrm{O}_{2}$ in water (GRATÃO et al., 2005), however, the APX has greater affinity for $\mathrm{H}_{2} \mathrm{O}_{2}$ when compared with CAT (GRAHAM; PATTERSON, 1982).

Regarding the activity of APX, a slight increase was observed in cultivar BRS Querência for the $50 \mathrm{~Gy}$ dose applied to the seeds and at doses above $50 \mathrm{~Gy}$ for the seedlings. In cultivar BRS Fronteira an expressive increase in the activity of APX, in seeds and seedlings for all the tested radiation doses (Figures 2C and 2D). CAT activity in seeds was similar to that observed with APX, not significantly differing between treatments in cultivar BRS Querência and showing a linear increase according to the radiation treatments in cultivar BRS Fronteira (Figures 2E and 2F). On the other hand, in the seedlings, the CAT did not follow the same trend presented by APX, and a small increase in its activity was observed only with the treatment with 50 Gy in cultivar BRS Fronteira. 
Table 2 - Ratio between shoots and root system in two evaluation dates (14 and 28 DAS) from two rice cultivars (BRS Querência and BRS Fronteira) subjected to different doses of $\mathrm{Co}^{60}$ gamma radiation.

\begin{tabular}{cccccc}
\hline \multirow{2}{*}{$\begin{array}{c}\text { Dose } \\
(\text { Gy })\end{array}$} & \multicolumn{2}{c}{ 14 DAS } & & \multicolumn{2}{c}{ 28 DAS } \\
\cline { 2 - 3 } \cline { 5 - 5 } & BRS Querência & BRS Fronteira & & BRS Querência & BRS Fronteira \\
\hline 0 & 2.0 & 2.1 & 3.4 & 3.2 \\
100 & 1.6 & 2.3 & 3.3 & 3.6 \\
150 & 1.1 & 2.3 & 3.9 & 3.6 \\
200 & 1.9 & 0.8 & 3.0 & 3.2 \\
\hline
\end{tabular}

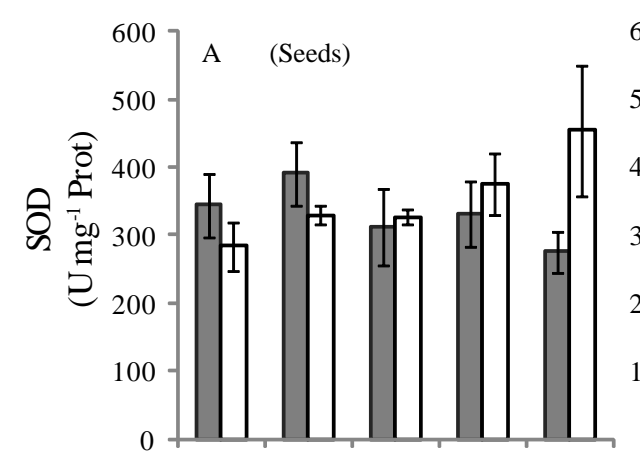

$$
\begin{array}{r}
600 \\
500-1 \text { B } \quad \text { (Seedlings) } \\
\\
\square \text { BRS Querência } \\
\square \text { BRS Fronteira }
\end{array}
$$
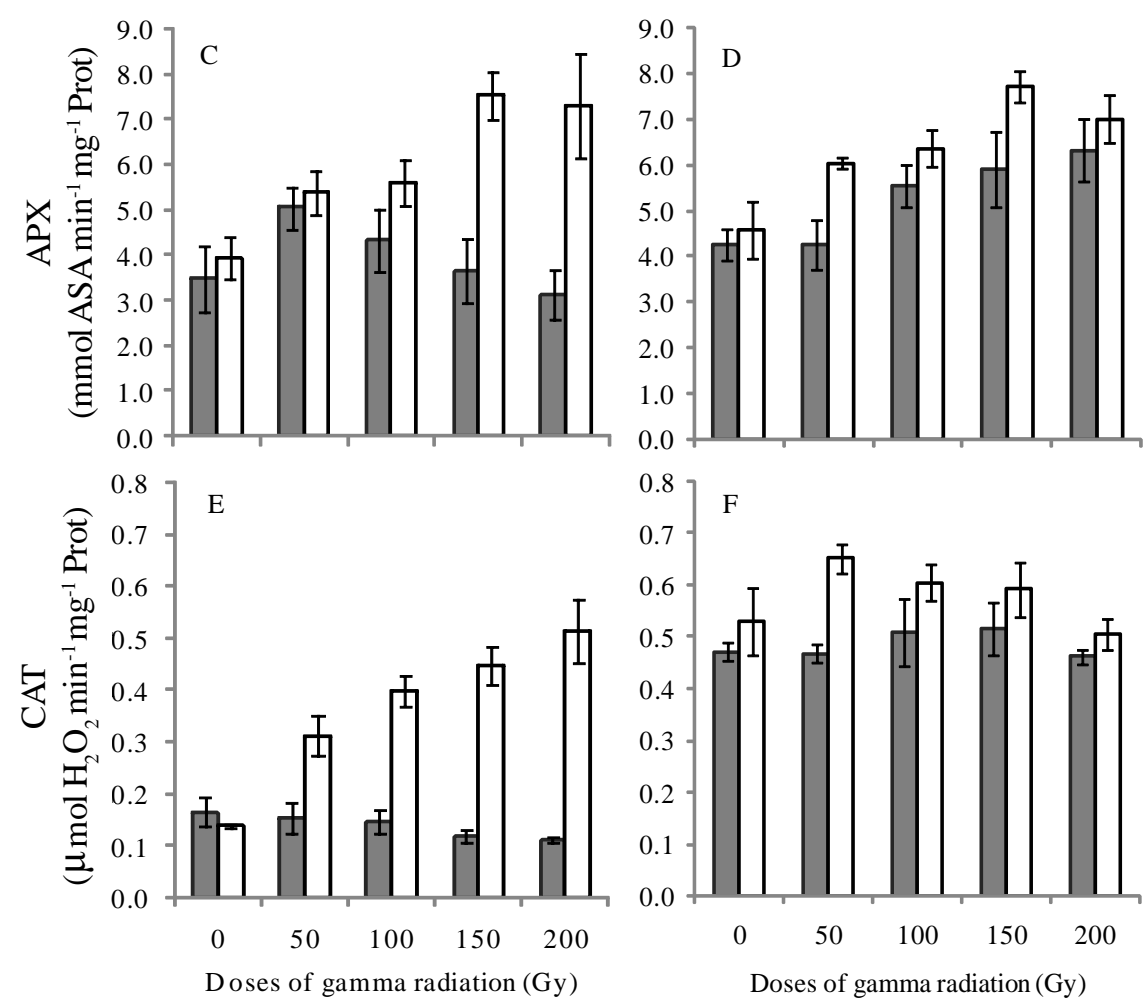

Figure 2 - Specifi activity of enzymes SOD (A-B), APX (C-D) and CAT (E-F) in two irrigated rice cultivars, BRS Querência ( $\square$ ) and BRS Fronteira ( $\square$ ) evaluated as seeds (first column) and seedlings (second column) at 10 days after sowing (DAS). Bars represent the standard error of the six replicate means. 
These results show that, in response to gamma radiation, there was an increase in ROS formation. These reactive molecules have traditionally been associated with non-specific damage to macromolecules, which can potentially result in cell death and ultimately in organisms death (POTTER et al., 2010). The toxic effects of ROS are usually kept at balanced levels by a synchronized action of antioxidant enzymes. The behavior of the two rice cultivars to the different levels of gamma radiation demonstrates that cultivar BRS Fronteira showed a higher expression of antioxidant enzymes, eliminating ROS more efficiently. This factor is important to prevent oxidative stress, thus allowing the development of seedlings, which may explain the better performance of this cultivar with regards to the growth parameters analyzed (Figure 1).

\section{CONCLUSION}

It follows from the above that the dose of $200 \mathrm{~Gy}$ significantly reduces the emergence and index emergence speed of seeds pre-hydrated in BRS Querência and BRS Fronteira cultivars. Among the parameters analyzed, the cultivar BRS Fronteira proves to be less sensitive to radiation, and this can be justified by a more efficient removal of ROS, thus preventing cell damage.

\section{REFERENCES}

AHLOOWALIA, B.S.; MALUSZYNSKI, M.; NICHTERLEIN, K. Global impact ofmutation-derived varieties, Euphytica, v. 135, p. 187-204, 2004.

ARTLIP, T.S.; WISNIEWSKI, M.E. Induction of proteins in response to biotic and abiotic stresses. In: PESSARAKLI, M. (Ed.) Handbook of plant and crop physiology. New York: Marcel Dekker, 2002. p.657-679.

AZEVEDO, R.A.; ALAS, R.M.; SMITH, R.J.; LEA, P.J. Response of antioxidant enzymes to transfer from elevated carbon dioxide to air and ozone fumigation, in the leaves and roots of wild-type and a catalasedeficient mutant of barley. Physiologia Plantarum, v.104, p.280-292, 1998 .

BAHL. J. R.; GUPTA, P. K. Chlorophyll mutations in mungbcan (Vigna radiata (L.) Wilczek). Theoretical and Applied Genetics, Berlin, v.63, p.23-26, 1982.

BROCK, R. D. Mutagenesis and crop improvement. In: CARLSON, P.S. Biology of crop productivity. New York, Academic, 1980. p.383-409.
BUMP, E. A. et al. Radiosensitization of hypoxic tumor cells by depletion of intracellular glutathione. Science, Washington. v.217, p.544-545, 1982.

CEPERO, L. et al. Stimulating growth of Leucaena leucocephala $\mathrm{cv}$. Cunningham with gamma rays from cobalt 60. Pastos y Forrajes, v.24, n.3, p.235-240, 2001

CHEEMA, A.A.; ATTA, B.M. Radiosensitivity studies in basmati rice. Pakistan Journal of Botany, v.35, n.2, p.197-207, 2003.

CROMARTY, A. S.; ELLIS, R. H.; ROBERTS, E. H. The design of seed storage facilities for genetic conservation. Rome: IBPGR, 1982, 182p.

DE LA FÉ. et al. Soybean seed radiosensibility to ${ }^{60} \mathrm{Co}$ gamma rays. Cultivos Tropicales, v.21, n.2, p.43-47, 2000.

DEUNER, S. et al. Stomatal behavior and components of the antioxidative system in coffee plants under water stress, Scientia Agricola, Piracicaba, v.68, p.77-85, 2011.

FAGUNDES, P. R. R.; ANDRES, A. Comportamento de linhagens clearfield da embrapa na Região Litoral Sul do Rio Grande do Sul - Safra 2006/07. Pelotas: Embrapa Clima Temperado, 2008. 4p. (Comunicado Técnico, 201).

FU, H. W.; LI, Y. F; SHU, Q. Y. A revisit of mutation induction by gamma rays in rice (Oryza sativa L.): implications of microsatellite markers for quality control. Molecullar Breeding. V. 22, p.281-288, 2008.

GAUL, H. Mutagen effects observable in the first generation. In: Manual Mutation Breeding, IAEA. Vienna, v. 85, p. 106, 1970.

GIANNOPOLITIS, C.N.; RIES, S.K. Superoxide dismutases: I. Occurrence in higher plants. Plant Physiology, Waterbury, v.59, n.2, p.309-314, 1977.

GRAHAM, D.; PATTERSON, B. D. Responses of plants to low non-freezing temperatures: proteins, metabolism and acclimation. Annual Review of Plant Physiology. v.33, p.347-372, 1982.

GRATÃO, P. L. et al. Making the life of heavy metalstressed plants a little easier. Functional Plant Biology, 32:481-494, 2005. 
GUDKOV, I. N.; GRODZINSKY, D. M. Cell

radiosensitivity variation in synchronouly-dividing root meristems of Pisum sativum L. during the mitotic cycle.

International Journal of Radiation Biology, Bristol, v.41, n. 4, p.401-409, 1982.

HAQ, M.S. Breeding for early, high-yielding and disease-resistant rice varieties through induced mutations. Rice Breeding with Induced Mutations III, IAEA, Vienna, p.35-46, 1971.

HUNG, D. C.; JOHNSON, K. Effects of ionizing radiation on the growth and allyl isothiocyanate accumulation of Wasabia japonica in vitro and ex vitro. In Vitro Cellular and Developmental Biology-Plant, v. 44, p.51-58, 2008.

KUMAR, G. Modification of radiation induced genetic damage and impaired DNA synthesis by thiourea treatment in Solanum incanum L. Cytologia, Tokyo, v.56, p.117-123, 1991.

MAITY, J.P. et al. Modulation of some quantitative and qualitative characteristics in rice (Oryza sativa L.) and mung (Phaseolus mungo L.) by ionizing radiation.

Radiation Physics Chemistry, v.74, p.391-394, 2005.

MIRANDA, H. L. C.; BOBROWSKI, V. L.; TILLMANN, M. A. A.; et al. Qualidade fisiológica de sementes de arroz submetidas à radiação gama. Ciência Rural, Santa Maria, v.39, p.1320-1326, 2009.

PLEWA, M. J.; DOWD, P. A.; SCHY, W.E. et al. Induced forward mutation at the yg 2 locus and a comparison with the ABCW relationship. Maize Genetics Cooperation Newsletter, Columbia, v.57, p.147-149, 1993.

POPINIGIS, F. Fisiologia da semente. Brasília : AGIPLAN, 1977. 289p.

POTTERS, G.; HOREMANS, N.; JANSEN, M.A.K. The cellular redox state in plant stress biology - A charging concept. Plant Physiology and Biochemistry, v.48, p.292-300, 2010.

RODRIGUES, L. R. F, ANDO, A. Caracterizaçãoe avaliação de três grupos de arroz-de-sequeiro de diferentes procedências por meio da sensitividade à radiação gama. Bragantia, Campinas, v.61, n.1, p.17-23, 2002.

SHAH, T.M. et al. Radio sensitivity of various chickpea genotypes in $\mathrm{M}_{1}$ generation I-laboratory studies.

Pakistan Journal of Botany, v.40, n.2, p.649-665, 2008.

VICCINI, L. F. et al. Resposta de sementes de milho à radiação gama em função do teor de água. Bragantia, Campinas, v.56, n.1, p.1-7, 1997.

WU, J. Thermal conductivity of some oxygenated fuels and additives in the saturated liquid phase. Journal of Chemical and Engineering Data, v. 50, n. 1, p. 102-104, 2005.

ZONTA, E. P.; MACHADO, A. A. SANEST -Sistema de análise estatística para microcomputadores. Pelotas, 1984.

Ciênc. agrotec., Lavras, v. 35, n. 6, p. 1093-1100, nov./dez., 2011 